\title{
Notes and Queries
}

\section{Author(s): S. M.}

Source: Kerry Archaeological Magazine, Vol. 4, No. 18 (Apr., 1917), pp. 147-148

Stable URL: http://www.jstor.org/stable/30059759

Accessed: 27-06-2016 09:34 UTC

Your use of the JSTOR archive indicates your acceptance of the Terms \& Conditions of Use, available at

http://about.jstor.org/terms

JSTOR is a not-for-profit service that helps scholars, researchers, and students discover, use, and build upon a wide range of content in a trusted digital archive. We use information technology and tools to increase productivity and facilitate new forms of scholarship. For more information about JSTOR, please contact support@jstor.org. 


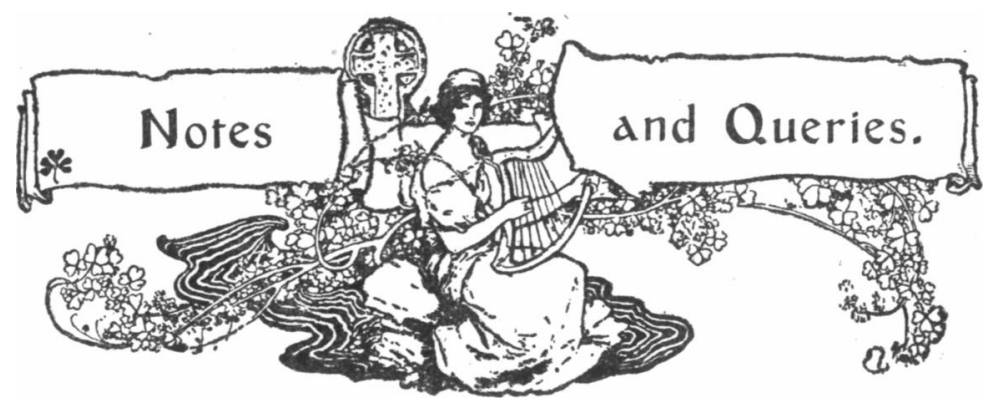

"FIGH'ING FITZGERALD."

In an interesting volume, recently published, called "The Devonshire House Circle," by Hugh Stokes, we find the following sketch of the above remarkable person:-

George Robert Fitzgerald was the elder son of George Fitzgerald of Turlough Park, Co. Mayo, some time an officer in the Austrian Service, by Lady Mary Harvey, sister of the 4th Earl of Bristol (who was Bishop of Derry). Educated at Eton, he became early notorious for duelling and gallantry. He ran away with the Duke of Leinster's cousin, heiress to $£ 10,000$, but she died soon after. In 1773 he was mixed up in a discreditable squabble over an actress at Vauxhall. He then married a second heiress, entered the world of politics, and preached the political independence of Ireland. On his estate in Co. Mayo he introduced hunting by night. The settlement of the family property brought about a complicated squabble with his father and brother, which he sought to solve by forcibly abducting his brother. For this, after some extraordinary adventures, he was committed to jail. The feud was gleefully taken up by the servants of the two parties, and one of his followers was arrested for wounding a certain McDonnell belonging to the other camp. In revenge McDonnell was beset by a hostile crowd of desperadoes, and, in the scuffle, a man was shot dead. Whether or no Fitzgerald fired the shot is far from clear; but he was recaptured, tried for murder, found guilty, and executed at Castlebar, July 12th, 1786. When Mr. Creevy was dining with the Earl of Lonsdale, in August 1827, the Earl said, "You have heard of Mr. Fitzgerald, 
who was called 'Fighting Fitzgerald,' whom I used to see a good deal of at Lord Westmoreland's. There was a man who bet a wager he would insult him; so going very near him in a coffee house he said, 'I smell an Irishman!' to which the other replied: 'You shall never smell another,' and taking up a knife cut off his nose."

[It is stated in Burke's "Landed Gentry," which gives a full account of the Fitzgeralds of Turlough, that they descended traditionally from Thomas Fitzgerald, 3rd son of Maurice, Knight of Kerry, who married the daughter and heiress of O'Dae or O'Dea, Chief of Ida in the Co. Kilkenny.]

There is of course no reason to doubt the accuracy of the above circumstantial statement, coupling a member of the Turlough family with the sobriquet which heads this note. But what about the following death announcement which appears in the issue of the "Cork Advertiser" for the 18th February, 1804, and which also bears the stamp of genuineness?

"Suddenly, at Northumberland Coffee House, Captain Fitzgerald of the Marines, commonly known as 'Fighting' Fitzgerald' from the number of duels he had been concerned in."

It would appear that there must have been more than one person named Fitzgerald who went by that title.

S. M.

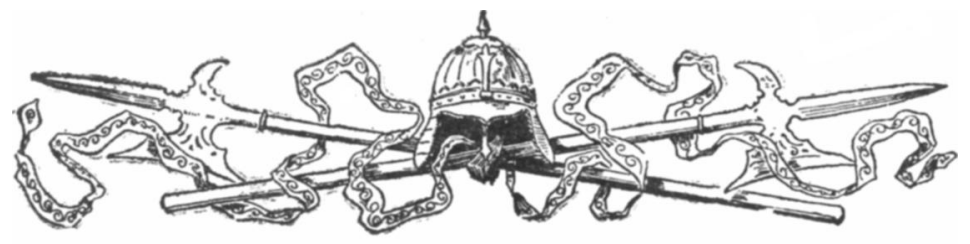

